\title{
VIETNAM AND CAMBODIA
}

\author{
We didn't even know who the Seychelles were. I had to Google it. \\ - Treaty negotiators, Cambodia
}

This chapter considers two Southeast Asian countries, Vietnam and Cambodia. In comparison with Zambia, both were late adopters of tax treaties: neither had a single bilateral tax treaty when they began to open up to FDI in the early 1990s. At that time, their attitudes toward investment promotion were not radically different, as illustrated by the tax incentives that both offered to foreign investors and their active BIT negotiation programs. Yet, while Vietnam has signed more tax treaties than almost any other lower-income country, Cambodia has taken a cautious approach, only beginning to sign treaties in 2016. In contrast to conventional explanations of the origins of tax treaties, which view the capital importer as the active pursuer of tax treaties, Cambodia declined requests for tax treaty negotiations from capital-exporting countries and tax havens for many years. Both countries received approaches from numerous capital-exporting countries seeking to enhance opportunities for their multinational investors, and felt competitive pressure to sign tax treaties in order to attract inward investment. Yet for a long time, only Vietnam acquiesced.

What explains this divergence? One difference between the two countries was timing. Vietnam urgently needed to replace its economic dependence on the Soviet Union after the end of the Cold War, and began to negotiate tax treaties in the early 1990s before it had a corporate tax system in place, seeing them as a shortcut to creating a tax regime for foreign investors. This urgency precluded a detailed consideration of a negotiating position, meaning that Vietnam allowed others to determine the content of its treaties. Cambodia, meanwhile, did not face such time pressure, imposing a much lower tax burden on foreign investors to 
begin with, and depending very little on tax revenue from businesses. By the time Cambodia faced real pressure to negotiate tax treaties, it desperately needed more tax revenue, creating a strong reluctance to sign away taxing rights. In contrast, Vietnam—like 1970's Zambia—had a large reservoir of state income that was unaffected by treaties, in this case from state-owned enterprises.

The consequences of these early choices are visible in the way in which these countries engage with international norms. Vietnamese officials have, since the late 1990s, engaged mostly with the OECD, rather than the UN. While they have become more strategic in their negotiating stance, they are motivated by the idea that all investment, no matter how small, and regardless of the costs or the level of competitive pressure, should be covered by a tax treaty. Vietnam has also used its domestic tax system to take unilateral steps that negate the main supposed investment-promoting benefits of tax treaties. Cambodia, meanwhile, selectively imported technical knowledge from abroad as it prepared to negotiate, strengthening its negotiating position while holding on to some unconventional ideas.

This chapter begins with a comparison of Vietnam's and Cambodia's approaches to international economic cooperation, including tax treaties. It then briefly demonstrates that both countries came under pressure from capital exporters to sign tax treaties. After this, the mechanisms within Vietnam and Cambodia are considered separately.

\section{Comparative Context}

Vietnam and Cambodia are neighboring countries in Southeast Asia. Both had somewhat closed economies until the beginning of the 1990s, when they began to open up to FDI. As figure 7.1 shows, FDI flows into Vietnam and Cambodia have been similar on a per capita basis since the early 1990s. One major difference between the two is the large role of state-owned enterprises and state investment in Vietnam's economy, in comparison with Cambodia, which has a much smaller state sector and relies much more on foreign enterprises for its economic growth. As a result, total investment per capita measured by gross fixed capital formation in Vietnam has been double that in Cambodia.

Tax treaties are a general exception to the pattern of participation in international agreements that we can observe for the two countries. Cambodia has usually followed closely behind Vietnam, participating in other forms of agreement within a few years (table 7.1). In contrast, the gap for tax treaties is a quarter of a century. While it is true that Cambodia has concluded fewer BITs than Vietnam, it had nonetheless signed twenty-six by 2017. ${ }^{1}$ Yet Vietnam and Cambodia are 


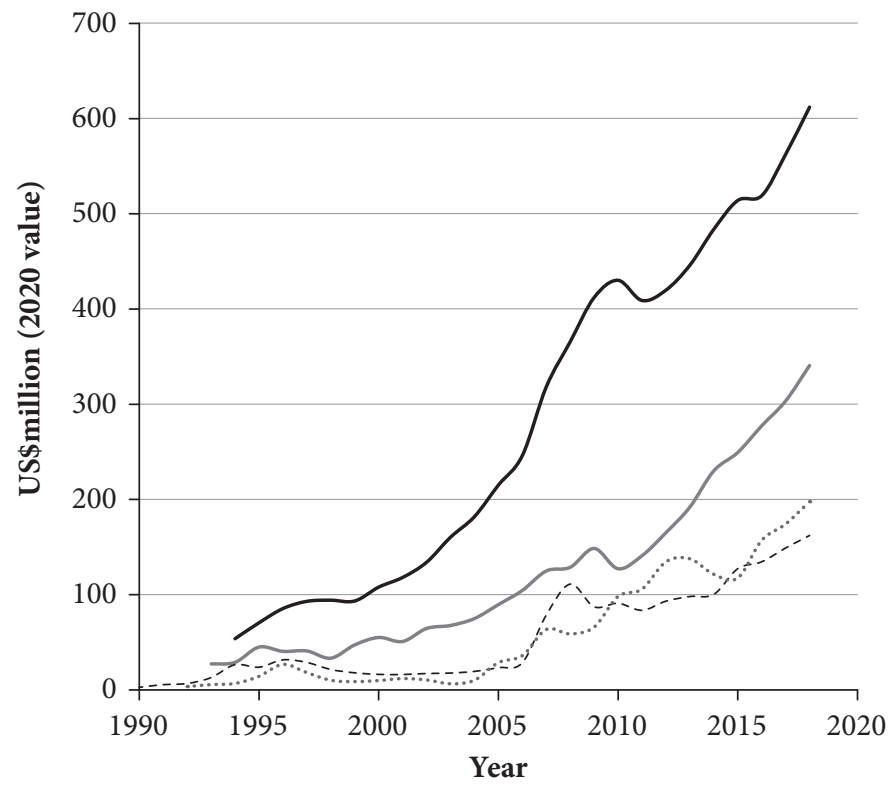

- Vietnam, Gross fixed capital formation

Cambodia, Gross fixed capital formation

Vietnam, Foreign direct investment

Cambodia, Foreign direct investment

FIGURE 7.1. Investment statistics per capita, Vietnam and Cambodia

Source: World Bank, “World Development Indicators," World Bank Open Data, 2020, http://data.worldbank.org.

TABLE 7.1. Timing of some key milestones in economic integration

\begin{tabular}{lcc}
\hline EVENT & VIETNAM & CAMBODIA \\
\hline First investment law & 1987 & 1994 \\
First BIT & 1990 & 1994 \\
First DTT & 1992 & 2016 \\
Joins ASEAN & 1995 & 2000 \\
Joins WTO & 2007 & 2004 \\
\hline
\end{tabular}

Source: IBFD, “IBFD Tax Research Platform,” 2020, http://research.ibfd.org/; Margaret Slocomb, An Economic History of Cambodia in the Twentieth Century (Singapore: NUS Press, 2010), 273-75; Pamela Sodhy, "Modernization and Cambodia," Journal of Third World Studies 21, no. 1 (2004): 153; UNCTAD, “International Investment Agreements Navigator," accessed August 10, 2015, http://investmentpolicyhub.unctad.org/IIA. 
TABLE 7.2. Treaty-making activity: Cumulative treaties signed

\begin{tabular}{lccccc}
\hline & \multicolumn{2}{c}{ BITS SIGNED } & & \multicolumn{2}{c}{ DTTS SIGNED } \\
\cline { 2 - 3 } \cline { 5 - 6 } YEARS & CAMBodIA & VIETNAM & & CAMBOdIA & VIETNAM \\
\hline Up to 1992 & 0 & 12 & & 0 & 2 \\
1993-97 & 6 & 37 & & 0 & 32 \\
$1998-2002$ & 13 & 45 & & 0 & 40 \\
$2003-7$ & 18 & 52 & & 0 & 47 \\
$2008-12$ & 21 & 64 & & 0 & 62 \\
$2013-17$ & 26 & 66 & 5 & 77 \\
\hline
\end{tabular}

Source: UNCTAD, “International Investment Agreements Navigator"; IBFD, “IBFD Tax Research Platform.”

polar opposites when it comes to their attitudes toward tax treaties. By 2017, Vietnam had signed seventy-seven tax treaties, while Cambodia did not sign any until 2016. Table 7.2 compares the cumulative number of tax treaties that both countries have signed since 1990 with the number of BITs.

To explain why the numbers of tax treaties signed by these two countries vary so much, this chapter uses secondary literature and field visits to Vietnam and Cambodia. Eleven semi-structured interviews were conducted in Vietnam (in total, four government officials, nine private sector stakeholders, and two others took part in interviews), and five in Cambodia (with two government officials and three private sector stakeholders). In both countries, the government officials responsible for tax treaty policy and negotiations were included in the sample. Sampling was largely purposive, with interviews arranged in advance through email. Government contacts were obtained through an OECD technical adviser who had been active in both countries, private sector contacts through the websites of private sector advisory firms, and other contacts through local NGOs. A small number of additional snowball-sampled interviews were arranged during field visits. In Vietnam, a government-industry consultation meeting on tax treaty interpretation was also observed. In Cambodia, both the lack of any tax treaties at the time of fieldwork and the embryonic state of the country's tax advisory sector reduced the number of potential interviewees available.

\section{Competition for Outward Investment Opportunities in Cambodia and Vietnam}

The competitive pressure on Vietnam and Cambodia is reflected in the growing number of treaties signed by countries within the ASEAN region, with which 
Cambodia and Vietnam compete for foreign investment and trade. Vietnam and the Philippines have used tax incentives to compete for high-tech manufacturers, for example, while Cambodia, Laos, and Myanmar compete in lower-technology sectors. ${ }^{2}$ In both of the case study countries, there was evidence of what appears to be a strategic interaction between lower-income countries, whereby one ASEAN country's signature of tax treaties creates pressure on another.

This is not, however, the only form of strategic interaction driving treaty diffusion. Since opening up, Cambodia has received multiple requests for tax treaties from both Asian and European countries (about ten, according to one government source). Among the countries that, as one official said, "have been writing many times in the past" are Malaysia, Thailand, Korea, China, and Japan. ${ }^{3}$ At least two of these countries have made formal requests in person via their ambassadors. ${ }^{4}$ Requests have also been received from European countries and more than once from the Seychelles. "We don't even know who they are," said one official, referring to the latter. "I had to Google it," said another. ${ }^{5}$

Vietnam has already signed a treaty with the Seychelles, despite no investment flowing between the two, according to its own statistics. Its large network of treaties signals to other countries that they will receive a positive response if they request negotiations, and many treaties have been initiated from the other country. "Normally when we negotiate with other countries, they decide when we negotiate," confirmed Nguyen Duc Thinh, the head of the International Taxation Department of the General Department of Taxation (GDT), interviewed in $2015 .^{6}$ While this confirms that the phenomenon of competition for outward investment described in chapter 3 is still relevant to the present day, the rest of this chapter focuses on decisions made in the lower-income countries.

\section{Vietnam}

Following the doi moi reforms of 1986, Vietnam's government began to open the country to FDI, passing a liberal investment law that was unusual in that it protected investors from subsequent changes in laws, as well as from expropriation. ${ }^{7}$ Furthermore, the new investment regime offered inward investors a tax holiday of up to eight years and a reduced tax rate thereafter. ${ }^{8}$ Progress in expanding political and economic relations with the rest of the world was initially slow after 1987, but came to be felt more urgently within the Vietnamese Communist Party when the fall of the Soviet Union left it marginalized. ${ }^{9}$ This is thought to have been one of the drivers of Vietnam's willingness to relinquish its military involvement in Cambodia through the Paris peace accords signed in 
1991, which in turn led to some thawing of relations with members of ASEAN, although it would take some time to establish trust. ${ }^{10}$

Vietnam threw itself into economic integration even before its domestic legal framework —including its tax laws_-had caught up. From 1990 onward it signed BITs at a ferocious pace of around six per year, with European and Southeast Asian countries as partners in roughly equal numbers. A surge in FDI in Vietnam in 1996 followed the lifting of the US trade embargo in 1994, which paved the way for Vietnam to finally join the ASEAN community in 1995, and eventually the WTO in 2007. ${ }^{11}$ The ASEAN and WTO logos still light up the main road from Hanoi's Nội Bài International Airport to the city center today.

Vietnam was no slouch when it came to tax treaties, either. It signed its first treaty in 1992, picking up the same, faster pace as for BITs soon afterward (table 7.2). The nineteen tax treaties signed by Vietnam between 1992 and 1995 already covered half of its inward investment, and by 1997 it had concluded a total of thirty-two treaties, now covering two-thirds of all its inward investment. ${ }^{12}$ In 1997, Vietnam formally expressed positions on the provisions of the OECD model tax treaty for the first time, reserving the right to include numerous beneficial clauses in its own treaties that are excluded from the OECD model. ${ }^{13}$ Figure 7.2 shows how the content of Vietnam's tax treaties changed over time, by comparing them with this declared negotiating position. There appear to be two distinct periods of negotiation: treaties signed between 1992 and 1998 were much more heterogeneous in their content and generally less reflective of Vietnam's own preferences. From 2000 onward, most treaties included 60-90 percent of the clauses that Vietnam had indicated in its negotiating position. While treaties with OECD member countries since 2000 have not tended to be as reflective of Vietnam's negotiating position as others, the same structural break can be seen from 2000 onward, suggesting stronger negotiating by Vietnam. Two specific examples of this structural break are as follows:

- Vietnam's position includes an additional paragraph 7 in article 5 of its tax treaties, giving it the right to tax companies that are "dependent agents" of foreign multinationals. This provision appeared in only half of Vietnam's 1990s treaties, but it was included in all of those signed since 2000.

- It also set out a position in favor of the right to levy a withholding tax on technical service fee payments to foreign contractors, which the model treaties do not permit. It was included in only a quarter of Vietnam's 1990s treaties, but is in more than half of those signed from 2000 onward. 


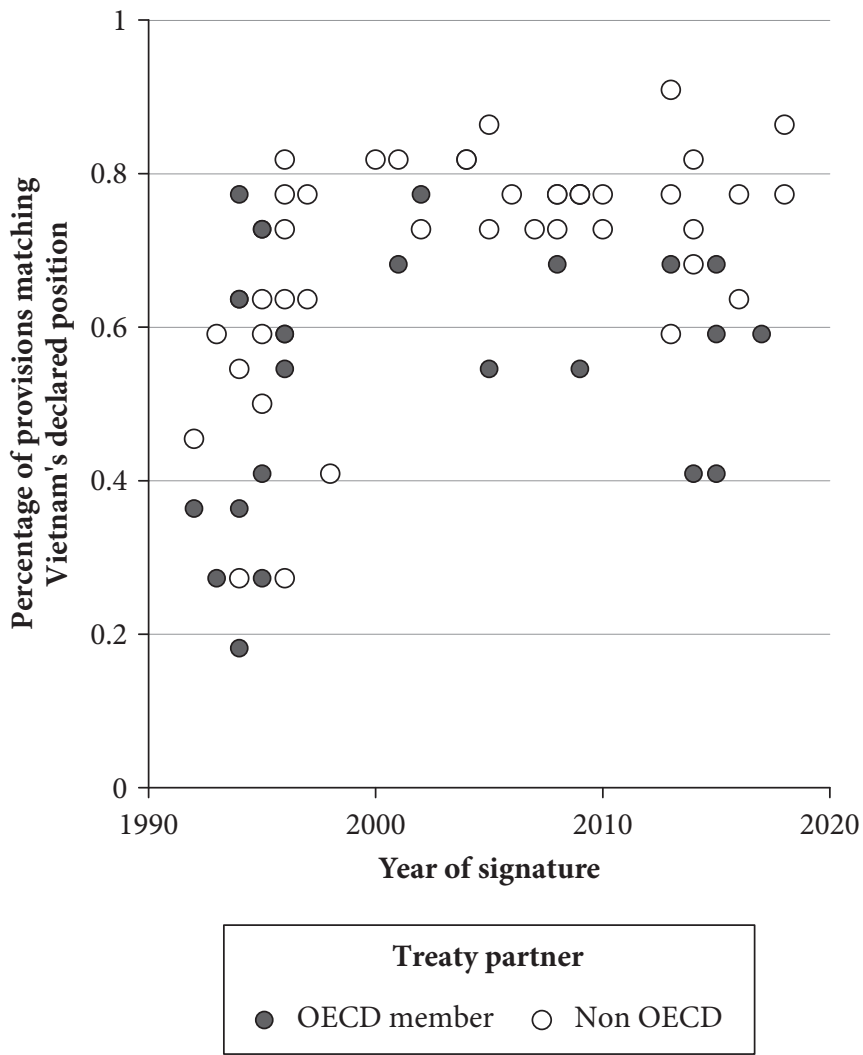

FIGURE 7.2. Vietnam's tax treaties scored against its declared position in reservations to the OECD model treaty

Source: Martin Hearson, “Tax Treaties Explorer," 2020, http://treaties.tax.

\section{A Treaty Network Driven by Competition for Inward Investment}

Interviews with current and former Vietnamese officials indicate that an intense desire to attract inward investment explains many of these early decisions. According to Thinh, three factors drove Vietnam's prolific negotiation of tax treaties and its willingness to make big concessions in the 1990 s. ${ }^{14}$ First, tax treaties and other economic agreements were ways of establishing political and economic relationships with other countries at a time when an economic embargo on Vietnam was still in place in the United States. This weakened Vietnam's negotiating strength. Second, by ensuring that all foreign investment was covered by tax treaties, Vietnam aimed to shortcut the development of domestic corporate tax 
laws, which would take considerable time at a point when there was a pressing need for inward investment. A third factor driving Vietnam's enthusiasm for tax treaties was a desire to have tax-sparing agreements with capital-exporting countries. Like Zambia in the 1970s, Vietnam in the 1990s was using generous tax incentives to try to attract inward investment; tax-sparing provisions in tax treaties ensured that foreign investors could benefit from the incentives in full. "This was our most vital condition for negotiating a DTA at this time. ... We had to step back [from other negotiating preferences] a lot because the tax sparing was so vital," said Thinh. ${ }^{15}$

Vietnam's weak position, combined with its lack of experience negotiating, meant that it made concessions that it would not now make. An official who had been involved in these early negotiations explained that Vietnam began its negotiations using the OECD model because it had not heard of the UN model. ${ }^{16}$ Thinh concurred: "During that time our negotiating partners were from the OECD and it was urgent to open our door and so we had to accept [OECD model treaty provisions $]$.... When we were beginning to negotiate DTAs, we didn't have so much experience. When the countries came to negotiate with us they forced us to use the OECD model." 17

As figure 7.2 indicates, however, it was not only with OECD members that Vietnam gave away large amounts of taxing rights. Among the pre-2000 treaties, aside from those with OECD countries, two are considerably less good deals than average for Vietnam. These are with Taiwan and Singapore, by far its two biggest sources of investment outside the OECD.

\section{The Low Importance of Fiscal Cost}

Vietnamese officials paid little attention to the costs of treaties they negotiated at this time because raising corporate tax from foreign investors was not a priority. "In Vietnam they don't care much about corporate income tax, it's VAT," one former civil servant explained to me. ${ }^{18}$ The country's tax system in the early years of its economic liberalization was complicated and discriminatory, incorporating taxes on turnover, profits, and profit disbursements. It was also administered inefficiently and somewhat arbitrarily by inexperienced and corrupt tax administrators. ${ }^{19}$ While this frustrated foreign-owned companies, they benefited greatly because they were exempted from turnover tax and taxed on their profits at a lower headline rate than domestic firms ( 25 percent compared with a maximum of 45 percent for domestic firms); furthermore, generous tax incentives in the Investment Law meant that most would not become liable for this tax for some time, if at all. ${ }^{20}$ 
As a result of this tax system, tax revenue from FDI was relatively small, as low as 0.02 percent of GDP in 1991, rising with the stock of FDI to 1.2 percent in 1997. ${ }^{21}$ But while tax revenue from foreign companies may have been low, Vietnam raised considerable revenue elsewhere. ${ }^{22}$ A paper coauthored by the head of tax policy in the Ministry of Finance notes that, despite difficulties in the administration of the tax system, Vietnam's tax-to-GDP ratio in the 1990s was much higher than other ASEAN countries that would have been expected to have greater "taxability" because of higher per-capita income and a greater industrial share in the economy. ${ }^{23}$

In part, this was because effective tax rates on domestic-owned firms in Vietnam were much higher than the rates in these other countries, exceeding 60 percent once turnover and profit taxes were taken into account. ${ }^{24}$ In addition, structural economic differences provided more tax revenue-in particular, the large share of state-owned enterprises in the economy, and the presence of the high-tax oil and gas sector (although revenue from the latter amounted to only around 2 to 3 percent of GDP). ${ }^{25}$ In 2000, tax revenue from foreign-owned firms still made up only 5 percent of total corporate income tax revenue, while more than four times as much came from state-owned enterprises. ${ }^{26} \mathrm{~A}$ new tax system promulgated in 1999 simplified the country's tax structure and made it less discriminatory. Foreign-owned firms now paid 33 percent tax on their profits, the same as domestic firms, but they still benefited from generous reductions lasting as long as ten years. ${ }^{27}$

\section{Treaty Negotiators: Limited Capacity but High Autonomy}

When Vietnam began to negotiate tax treaties, its negotiators had little prior exposure to the international tax community. ${ }^{28}$ Absent technical knowledge and negotiating experience, their approach to concluding tax treaties was incoherent. In the late 1990s, however, "some OECD experts came to Vietnam to talk about the DTAs," according to Thinh. ${ }^{29}$ Vietnamese officials became a regular fixture at the OECD's annual Global Forum on Tax Treaties during the 2000s, sending a delegation of two to four persons each time. ${ }^{30}$ In contrast, Vietnam did not attend annual meetings of the UN Tax Committee until 2017. ${ }^{31}$

While government officials outside the GDT still reproduce the tax treaties myth, ${ }^{32}$ this is not the only logic at work within the GDT itself. Rather, Vietnam has adopted the policy that all investors, no matter how small, should be covered by a tax treaty. "Even if it is a small amount of investment it is still worth it," according to Thinh. This contributes to one business representative's view that "Vietnam's negotiations have been on a 20 -year roll." ${ }^{33}$ While Thinh and his colleagues 
want all investors to be covered by a treaty, it is very clear, from interviews and from their approach to applying tax treaties, that this is because they want to apply an international standard to all existing inward investors, not merely to encourage new inward investment.

Among private sector tax practitioners with experience dealing with the GDT, Thinh was described as the driving force behind decisions related to tax treaties. ${ }^{34}$ He also suffered from a lack of experienced support: according to a former employee within the International Tax Department, in 2015 Thinh was the only member who had been in his post for more than five years, out of a staff of twelve. ${ }^{35}$ According to one European tax lawyer who has worked in the region for over a decade, “It's all about people. If Vietnam didn't have Mr Thinh they wouldn't have any tax treaties." ${ }^{36}$ A former official from the Department of Trade stated, "The legacy of signing agreements all the time is set in momentum, and it keeps on going. ... Sometimes it just happens because someone gets in the routine."37

It is notable, however, that the GDT's authority does not extend to being able to implement its desire to renegotiate treaties. The country has accepted an offer from the Netherlands to renegotiate in order to add an anti-abuse clause to that treaty, but while some lower-income countries have faced difficulties persuading higher-income countries to renegotiate treaties that are a good deal for the latter, Vietnam does not appear to have tried. As in Zambia, the main reason relates to internal bureaucratic politics. According to Thinh: "Nowadays ... we would like to renegotiate. From our side, it's not easy because there would be questions from the other ministries and agencies. They would ask why we should want to. For example, we really want to renegotiate with France, because we don't have an interest article, but the other ministries would say 'everything is fine, why do you want to do this?'”

\section{The Legacy of Past Negotiations}

Today, it is much less clear what Vietnam stands to gain from its tax treaty negotiations. In 2005, it decided to abolish withholding tax on profits remitted by foreign investors as dividends, and reduce withholding taxes on interest, royalties, and service fees to very low rates. ${ }^{38}$ This dramatic move made its tax system much more attractive but also undercut the main supposed investment-promotion tool of its tax treaties. As Vietnam also no longer prioritizes tax-sparing clauses within its treaties, ${ }^{39}$ the tax treaty provisions that might be expected to have the biggest investment-promoting effect are no longer of relevance to investors in Vietnam.

Furthermore, when I visited in 2015, Vietnam's application of its tax treaties was directly undermining the benefits that investors might have hoped to gain. 
We can see this by looking at the example of Vietnam's approach to PE, the threshold test that establishes when a foreign company operating in Vietnam becomes liable to pay income tax on its profits. In almost all tax treaties, a company must have a physical presence in a country for a certain period of time to meet this test, subject to some exceptions. In contrast, the criteria in Vietnamese law were much more broad, simply that most companies "who do business in Vietnam or earn income in Vietnam" were liable to income tax. ${ }^{40}$ In theory, therefore, any investors who were sensitive to their tax liability should have regarded a tax treaty with Vietnam as an important curb on what many regarded as its aggressive approach to taxation. But Vietnam had chosen to interpret the PE provisions of its treaties in unconventional ways that, according to a typical statement from the VBF (which represents overseas investors), "made the application of DTA[s] of foreign enterprises impossible, effectively it obliterate[s] the legitimate benefit of enterprises." 41 Vietnamese negotiators seemed to want to eat their cake and have it, simultaneously demonstrating their support for the policy project of disseminating OECD standards through tax treaties, and ignoring those standards where they prevented Vietnam from taxing as it would like.

For example, a common difference between the two main models on which tax treaties are based is the provision for a "services PE." Under the OECD model, which favors capital exporters, a foreign company providing services in Vietnam must have a fixed place of business in the country, such as a registered office, to be taxable. Vietnam has expressed a position on the OECD model stating that in its treaties it will seek to include a provision from the UN model that lowers this threshold by permitting it to tax such a company simply if its employees are physically present for a certain period, even without a "fixed place of business." Although more than two-thirds of Vietnam's treaties in force include this service PE provision, it is omitted from many of its older treaties and from treaties covering almost two-thirds of its inward FDI. Vietnam's response to this unsatisfactory situation was to take the position that, absent a service PE provision in a treaty, it was at liberty to tax service providers without any minimum threshold, the exact opposite of how tax treaties are usually interpreted. ${ }^{42}$

The inconsistency between negotiation and administration priorities was not a result of inconsistency between parts of the bureaucracy, because decisions on both were made by the GDT. Vietnam's tax administration is decentralized, and according to tax advisers, its local offices do not have the knowledge to apply tax treaty provisions effectively. ${ }^{43}$ They rely on circulars issued by the GDT in Hanoi. Senior officials at a consultation meeting between VBF members and the Ministry of Finance in August 2015 repeated the line in these circulars. ${ }^{44}$ Investors' lack of confidence in the independence of the courts meant that no tax treaty case had 
ever been tried in a court, despite the clear frustration from many investors and their advisers. ${ }^{45}$ Administrative appeals, according to tax advisers, were always settled by the International Tax department, which drafted the circulars against which the appeals were directed. "The Deputy Director of the GDT signs off rulings," said a tax adviser. "If there's a dispute you can escalate it to the deputy Minister of Finance, but ultimately it will just go back to Mr Thinh." ${ }^{\prime 6}$ The result of this system was that companies did not avail themselves of benefits to which they were entitled according to the treaty. "A lot of companies could claim [reduced taxation] under treaties, but they don't. It's too much hassle," stated one interviewee, while another went as far as to state, "I am not aware of foreign investors obtaining treaty benefits." 47

The consequence of Vietnam's position was that investors paradoxically had less certainty under treaties than without them and, worse, that Vietnam's treaties created double taxation rather than eliminating it. This latter effect came about because treaty partners generally refused to give their outward investors a credit against tax paid in Vietnam if, in their view, Vietnam should not have the right to levy tax under the treaty (in the absence of a treaty, they would be likely to give a credit in the circumstances described here). Following a US\$1 billion investment by Samsung in the country, businesses from Korea, covered by one of Vietnam's earliest and most regretted - by the GDT_-treaties, invoked a dispute settlement procedure in the treaty to try to challenge some of these interpretation issues, because they did not expect domestic remedies to make a difference. ${ }^{48}$ Disputes were also triggered by Samsung's Dutch and Japanese suppliers. Large sums were involved. ${ }^{49}$

\section{Vietnam: Conclusion}

During the 1990s, Vietnam had sought tax treaties to bring in inward investment, establishing political and economic relations with countries following economic liberalization and the fall of the Soviet Union, and making up for its lack of a domestic tax code. The tax costs they created were not anticipated by officials in this early period, and thus caused problems later when companies expected to benefit from these treaty provisions. A main priority in this early period was taxsparing clauses, but in other areas Vietnam was negotiating without a clear sense of the specific provisions that were important to retain its tax base, because raising tax revenue was not a priority.

Since 2000, greater technical knowledge within the GDT means that Vietnam has negotiated on a much more consistent, assured basis with a wide range of countries including many where there is neither competitive pressure nor a prospect of inward investment. Accompanying this technical knowledge is the 
idea that all investment, no matter how small, should be covered by a tax treaty. When I visited in 2015, the office within the GDT that negotiates and applies tax treaties appeared unwilling to reconcile this belief with the reality of administering tax treaties, interpreting them in ways that rendered them largely ineffective. As one tax lawyer put it, "They should be looking into the OECD interpretations if they're serious. As it is, it's [tax treaties] just window dressing." 50

\section{Cambodia}

Cambodia's current political era begins with the Paris peace accord in 1991 that formally ended conflict between its warring factions, and the involvement of eighteen other countries in its domestic affairs. ${ }^{51}$ Private enterprises had not been recognized by the Cambodian state under the Khmer Rouge, and private property rights were not restored until 1989. ${ }^{52}$ On September 21, 1993, Cambodia's new constitution was adopted by its newly elected Constituent Assembly, and an elected government took office. Policymaking in this era was predominantly dictated by outside experts, especially when Cambodia agreed to a Structural Adjustment package in $1994 . .^{53}$

The new government in 1994 established for the first time a formal tax system based on self-assessment, replacing what had previously been an "estimated" regime, in which tax officials calculated a firm's estimated profit and then "negotiated" with the taxpayer. ${ }^{54}$ But it was not until 1997 that a Western-style tax system was introduced, with taxes on profits and withholding taxes on certain types of payments. Before this, tax treaties may have made little difference.

In August 1994, Cambodia signed its first BIT, with Malaysia, and passed the Cambodian Investment Law, which offered investors in certain sectors generous incentives including an eight-year corporate income tax holiday (the same as Vietnam) and an exemption from tax on dividend payments. ${ }^{55}$ There was a setback in investment promotion in July 1997, when the Cambodian People's Party (CPP) instigated a coup. Combined with the Asian financial crisis, this temporarily slowed inward investment in Cambodia; but with successful elections in 1998 placing the CPP in power on a more legitimate basis, Cambodia's integration into the global political economy continued. ${ }^{56}$

In 2004, Cambodia began to seriously consider the idea of signing tax treaties and started work to develop a negotiating model. ${ }^{57}$ In 2008, an international tax bureau, tasked with treaty negotiations, was formed within the newly created GDT. But it was not until 2014 that Cambodia opened talks. By 2015, it had completed the first round of negotiations with Vietnam and Thailand and was in correspondence with Brunei, Laos, and Singapore. ${ }^{58}$ Agreements were signed in 
2016 with China and Singapore, in 2017 with Brunei, Indonesia and Thailand, and subsequently with Vietnam and Korea.

\section{Peer Pressure}

All the interviewees situated a shift by Cambodia into negotiating mode in the context of its historical reluctance to sign tax treaties. It is clear that Cambodia has felt pressure to sign tax treaties for some time, not because investors face great obstacles created by double taxation but because it had become increasingly isolated within the region as the only country without a DTT (table 7.3).

In 2008, ASEAN members signed an Economic Community blueprint, which stated that members will "work towards establishing an effective network of bilateral agreements on avoidance of double taxation among ASEAN countries." 59 Though Cambodia was still reluctant, the momentum this created among its neighbors such as Laos and Myanmar_direct competitors for investment-was the final straw. "It's an international tax trend, our neighbours are signing them," said a government official. ${ }^{60}$ Tax advisers in the private sector concur. "The government had no intention of signing tax treaties. But now that Myanmar is open, they are considering if we have got behind," said one. ${ }^{61}$ Another agreed: "They're under a lot of pressure from everywhere because they hesitated for a very long time. They have considered a lot and they don't want to do it, but because of the pressure from the private sector and government-even Myanmar is doing it now-Cambodia is the only one left." ${ }^{2}$

TABLE 7.3. Tax treaties signed by ASEAN member states

\begin{tabular}{lrcr}
\hline & & TAX TREATIES SIGNED & \\
\cline { 2 - 4 } CountRY & $\mathbf{1 9 9 7}$ & $\mathbf{2 0 0 7}$ & $\mathbf{2 0 1 7}$ \\
\hline Brunei* & 0 & 8 & $\mathbf{2 6}$ \\
Cambodia & 0 & 0 & 5 \\
Indonesia & 51 & 73 & 80 \\
Laos & 2 & 6 & 13 \\
Malaysia & 63 & 88 & 100 \\
Myanmar & 1 & 7 & 10 \\
Philippines & 35 & 44 & 50 \\
Singapore & 44 & 73 & 106 \\
Thailand & 39 & 66 & 73 \\
Vietnam & 32 & 47 & 77 \\
\hline
\end{tabular}

Source: IBFD, “IBFD Tax Research Platform."

*Three treaties concluded prior to Brunei's independence from the United Kingdom are excluded. 
Cambodian officials emphasize that their own capacity development has been slow, and believe that Laos and Myanmar have made a mistake by negotiating treaties at a similar stage of capacity development rather than forming a firm position based on more detailed technical knowledge first. ${ }^{63}$

\section{Importance of Fiscal Costs}

A comparison of tax performance in Cambodia and Vietnam (figure 7.3) may help explain why Cambodian officials took a different attitude toward tax treaties. In 1995, the first year for which data are available, Cambodia raised tax revenue amounting to as little as 5.3 percent of its GDP and was highly aid-dependent, receiving twice as much government revenue through aid than through taxation. ${ }^{64}$ Revenue from corporate taxation was negligible. More than half of its government tax revenue came from trade taxes, a disproportionately high amount compared with other lower-income countries. ${ }^{65}$ Cambodia's corporate income tax rate at this time was 20 percent, low in comparison with other countries in the region, and in practice foreign investors could pay much less, as a result of eight-year tax holidays that were followed by a permanent 9 percent preferential tax rate. They were also exempt from withholding taxes on certain dividend, interest, and royalty payments. With such generous treatment for foreign investors already in the domestic tax code, tax treaties were not a high priority.

Increasing corporate tax revenue became an important priority for the Cambodian government in the late 1990s. A World Bank report from 1998 notes that "Cambodia's current revenue-to-GDP ratio is very low by international standards. . . . The Law on Investment is one of the most critical impediments to improved revenue mobilization.... The combination of the Law and the [implementing] Regulations has eliminated any room for the business income tax to be a policy instrument in the revenue mobilization effort."66

Cambodia began to target reforms to its business tax law and administration, and tax revenue from businesses steadily began to increase, by tenfold as a share of GDP between 1996 and 2016. By the mid-2000s, taxes on businesses made up 15 percent of total tax take, and by 2016 almost a quarter. The Cambodian government had become dependent on taxes on businesses, while its private sector was also heavily penetrated by foreign investment: this would increase demand for tax treaties but make the revenue costs especially significant. According to one interviewee, a GDT study conducted in around 2013 estimated the impact of reduced withholding tax rates, were Cambodia to sign a treaty with Vietnam, at between US\$5 million and US\$6 million per year. ${ }^{67}$ If correct, this would have been a cost of around 2 percent of Cambodia's total tax revenue from businessesfrom just one part of one treaty. 


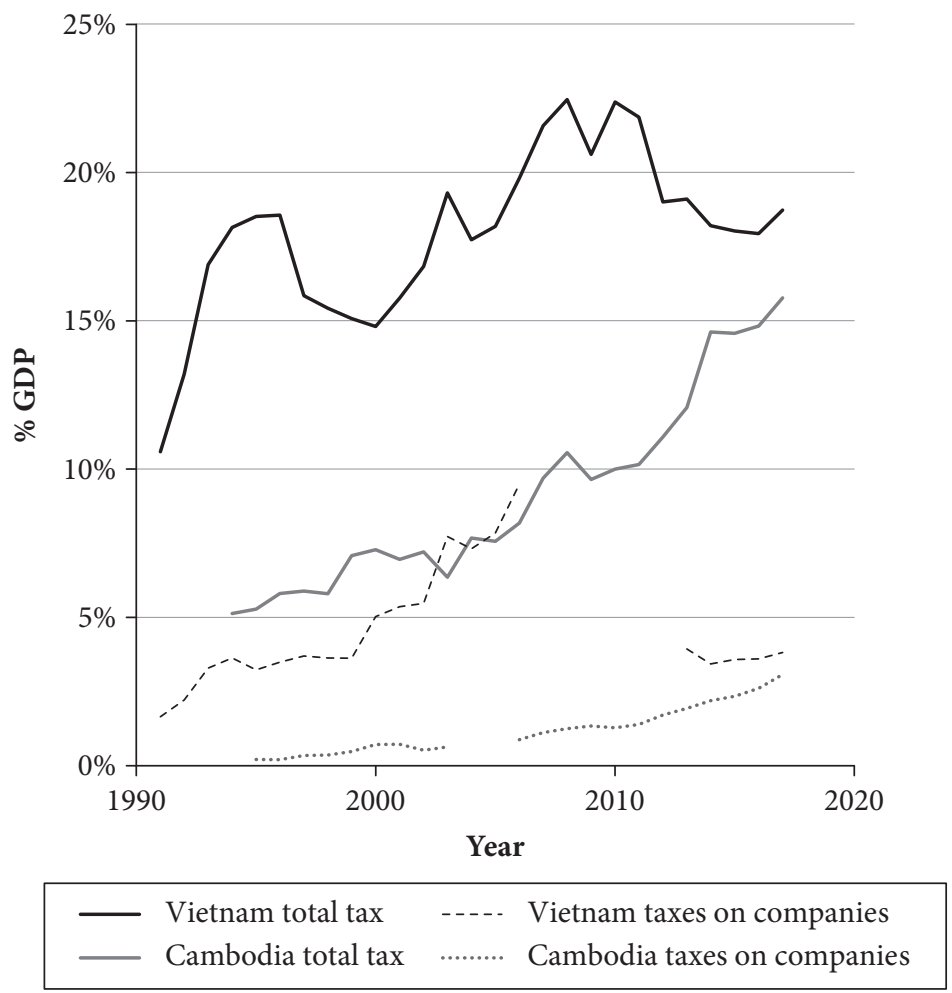

FIGURE 7.3. Selected tax statistics from Vietnam and Cambodia

Source: ICTD/UNU-WIDER, “Government Revenue Dataset,” UNU-WIDER, 2020, https://www.wider.unu.edu/project /government-revenue-dataset.

Contrast Cambodia with Vietnam. For the latter, tax revenue from businesses was also an important part of government revenues during the 1990s, but with two important differences. First, overall tax revenues were much higher, mostly between 18 and 20 percent of GDP. Second, much of this tax revenue came from state-owned enterprises, joint ventures, and locally owned businesses. As we saw earlier, FDI represented a much smaller share of total investment, and hence of the tax base. Vietnam also taxed foreign investors more heavily than did Cambodia. The result was that tax treaties made a bigger difference to investors in Vietnam, and had smaller costs to the government as a share of total revenue.

This comparison is supported by interview evidence. Edwin Vanderbruggen, a Dutch tax lawyer practicing across Southeast Asia who advised the GDT on its tax treaty policy, noted that concern about lost revenue was uppermost in the Cambodian officials' minds. In contrast to BITs, he said, tax treaties have an immediate upfront cost. "[The Cambodians] had no understanding of how tax 
treaties worked, but they did understand that you can't sign tax treaties and not lose anything. They had a very small tax base to begin with." 68

Tax advisers in the private sector also attributed the continued reticence, including the lack of allocation of human resources to tax treaties until around 2014, to an institutional preoccupation with their fiscal costs. "The GDT is the tax policymaker, execution and judge. When the government set their own revenue KPIs they don't look into the long term, that's why they don't sign," stated one. ${ }^{69}$ "They don't want to move quick and incur a lot of loopholes," said another. ${ }^{70}$

\section{Building Technical Knowledge}

As the pressure on Cambodia to sign treaties rose, it proceeded to develop a treaty policy cautiously, taking ten years before entering into negotiations, and put in place plans to monitor the impact on revenue of its first few treaties. The final push leading to the opening of negotiations was created by the appointment of a new director general (DG) at the GDT. "When the former DG Sin Yay was replaced by Kong Vibol, this gave it a new impetus. He's much more international," said one. ${ }^{71}$ Another agreed that "the previous DG was quite narrow-minded. After the change of DG they started looking into a lot of issues. They started quickly on DTAs but it took a lot of time for them to understand. I thought it was just a matter of time."72 But Cambodia's international tax bureau still had only four people in 2011, one of whom was studying abroad, and one of whom was actually dedicated to other work. "We had very few human resources, and those human resources were not fit for the job," said one of the civil servants interviewed, who is in a management position within the international tax bureau. He added, "The very day I started, I didn't know what a DTA was."73

In this context, external advisers had considerable influence. From the beginning, Cambodia has relied on outside experts with greater expertise than its own staff. Vanderbruggen was hired as a full-time adviser in 2006, to develop a model treaty for use in negotiations. ${ }^{74}$ Cambodia also received technical assistance from Australian and Japanese experts (the first a former treaty negotiator) as well as the OECD, Asian Development Bank, and World Bank, and its officials have attended numerous external training courses. ${ }^{75}$

Cambodian officials have identified several areas where treaties that use the conventional rules of international taxation were likely to have a significant impact on the country's revenues, and where they wanted to pursue an unconventional approach. Three of these are the taxation of foreign airlines, insurance companies, and international coach travel. ${ }^{76}$ Cambodia currently levies a tax on half the gross value of tickets sold for flights to and from the country, on the gross value of insurance premiums paid by Vietnamese residents, and on the busy coach routes be- 
tween Ho Chi Minh City, Phnom Penh, and Bangkok. Officials wanted its treaties to permit this to continue. The model treaties, however, state that businesses should be taxed only on their net profits, not gross income, in these circumstances. Airlines are specifically exempted from taxation in operating countries unless they have a PE that generates profits (yet, as a government official wryly observed, state subsidies mean that most airlines flying to Cambodia make a loss, so there is no net profit for Cambodia to $\operatorname{tax}^{77}$ ); the UN model makes an exception for companies selling insurance premiums, treating them as having a PE, while no such exception applies in the OECD model; the international travel article makes no mention of coach companies, which means they can be taxed only if they fall under the conventional PE article.

Cambodian officials have negotiated very well so far (figure 7.4). Its agreements with Thailand, Singapore and Korea compare especially favorably with those signed by Vietnam, when it was also at an early stage of its negotiating history. Cambodia's agreement with China leaves fewer taxing rights intact than Vietnam's, but this is unsurprising given that China has become a far tougher negotiator since it signed with Vietnam in $1995 .^{78}$ Nonetheless, Cambodia's negotiators have struggled to maintain their unconventional positions in the face of overwhelming technical consensus that these positions contravene the acceptable standards of the model treaties. According to Vanderbruggen, who drafted Cambodia's model tax treaty,

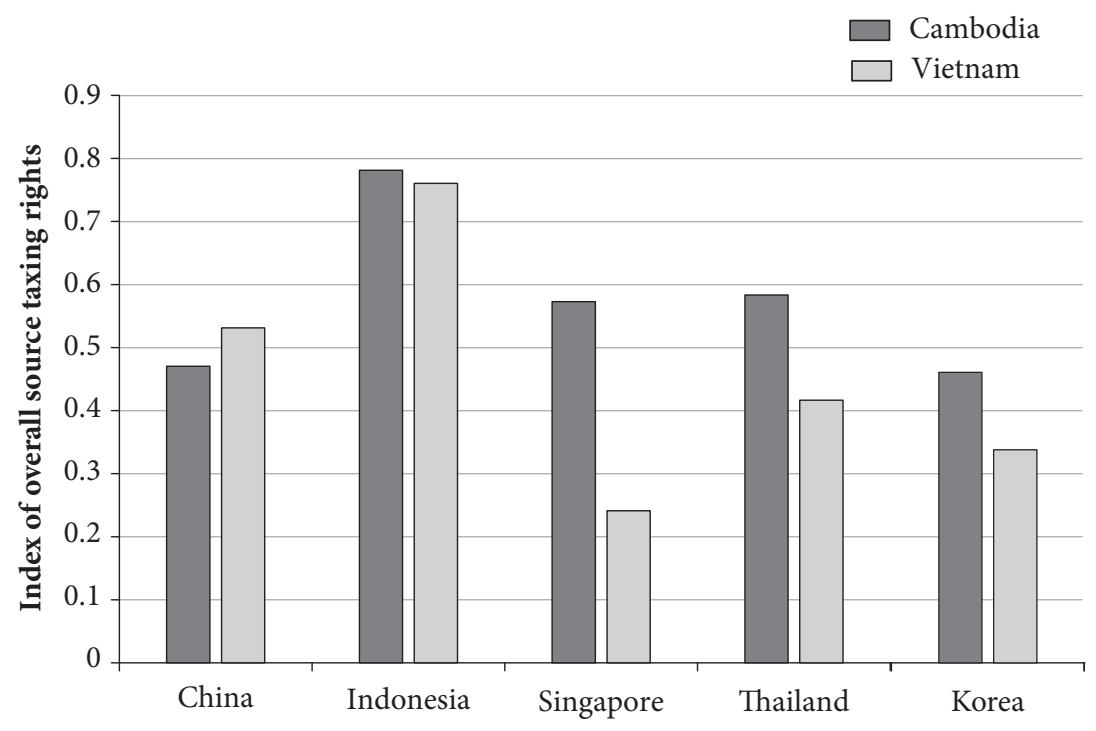

FIGURE 7.4. Cambodia's and Vietnam's negotiations compared 
"I said, 'you cannot be the only country in the world that goes against the OECD, UN and ASEAN model [treaties]." 79 Said a negotiator, "Your counterpart just tells you that this is not the international standard." ${ }^{80}$ For this reason none of Cambodia's treaties allow it to tax airlines from the treaty partners in the way that it wanted to retain. It appears to have had more success on insurance, since it can refer to the authority of the UN model in support of its position. As for coach travel, Cambodia drafted alternative wording in its model treaty, which appears to have been secured in its negotiations with Vietnam and Thailand, the two countries with which it was most relevant.

\section{Cambodia: Conclusion}

Cambodia was not late to sign tax treaties because of a lack of competitive pressure. Rather, it actively resisted this pressure in terms of both comparing itself with competitor countries and accepting requests from potential treaty partners to open negotiations. The lack of treaties is also not a result of a reticence to conclude economic agreements with other countries, or of an unwillingness to use its tax system to attract investment, something that international organizations suggested it did too much of. In the early years, there was little need for tax treaties, while the later reluctance to negotiate seems to have resulted from an acute awareness of their fiscal costs, at a time when the government had become dependent on its relatively low revenues from taxes on businesses. It was only once Cambodia's direct competitors had all concluded some tax treaties that government officials reached the conclusion that the costs of not signing treaties exceeded those of doing so. The basis on which this decision was made came not from evidence, such as seeing a positive effect on investment among their competitors (who in fact the Cambodian negotiators believe had made mistakes in signing treaties), but from a feeling that Cambodia could not be the only ASEAN member with no tax treaties.

\section{Case Comparison}

Vietnam and Cambodia are outliers_-positive and negative, respectively. Vietnam has one of the widest treaty networks of any lower-income country, motivated by a combination of tax competition and an assurance to inward investors that they will be taxed according to international standards. Its earlier treaties were effectively blank checks, signed before Vietnam had properly established a tax regime and certainly before it had developed a comprehensive negotiating position. Government officials were prioritizing the use of tax treaties to overcome 
other deficiencies that might discourage inward investment, without first forming a complete understanding of the implications of the agreements they were signing. A large pool of revenue from state-owned enterprises meant that, in the tradeoff between investment promotion and the fiscal costs of tax treaties, the latter was much less of a concern to policymakers. Today, with revenue raising from foreign companies a higher priority and much more experience of negotiating and applying treaties, Vietnam's GDT is trying to undo some of its earlier mistakes. The binding nature of its treaties combined with politics within government means that it has been forced to do this via unconventional interpretation that contravenes the same international standards that, in principle, it supports through its treaty negotiations.

Cambodia, in contrast, has been a model of how countries should approach treaty negotiation. By the time it was ready to consider tax treaties, corporate tax revenue-and in particular from foreign-owned companies-had become an important part of government revenues, which made the tax costs a more significant concern. Having resisted invitations to begin negotiations for years, Cambodia opened discussions only after a decade-long period of capacity building and policy development, avoiding the mistakes that Vietnam and Zambia had made. It identified particular areas where international standards would impose undesirable tax costs, and although its negotiators came up against the power of the model treaties and the consensus within the tax community, it has managed to carve a distinctive path that protects its interests, at least partially. 